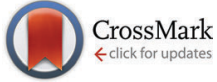

Cite this: New J. Chem., 2015 39,6274

Received (in Montpellier, France) 30th April 2015,

Accepted 2nd June 2015

DOI: $10.1039 / c 5 n j 01088 h$

www.rsc.org/njc

\section{Conformational insights and vibrational study of a promising anticancer agent: the role of the ligand in $\mathrm{Pd}(\mathrm{II})$-amine complexes $\dagger$}

\author{
Sónia M. Fiuza, ${ }^{* a}$ Ana M. Amado, ${ }^{a}$ Stewart F. Parker, ${ }^{b}$ Maria Paula M. Marques ${ }^{\text {ac }}$ and \\ Luís A. E. Batista de Carvalho ${ }^{a}$
}

A conformational and vibrational analysis of an antiproliferative spermine-based dinuclear Pd(॥) complex $\left(\mathrm{Pd}_{2}-\mathrm{Spm}\right)$ is reported. Density functional theory coupled to all-electron basis sets was used to perform quantum mechanical calculations aimed at determining the strategy best suited for accurately representing this molecule and achieving an optimal accordance with the experimental data. The structural parameters and the vibrational frequencies predicted by the calculations are compared with the corresponding experimental data. The results support a relationship between the strength of the metal-ligand bonds and the antitumor activity of the compound.

\section{Introduction}

Palladium(II) complexes are an emerging class of inorganic compounds bearing recognizable anticancer properties, ${ }^{1-5}$ challenging the initial belief that complexes containing this metal centre would be inactive. This conviction started to materialize with the lack of biological activity of the parent compound cisdiamminedichloropalladium(II) (cDDPd), ${ }^{6}$ as opposed to its Pt(II) homologue (cisplatin, cis-diamminedichloroplatinum(II), cDDP) that was justified by the higher lability of palladium(II) complexes relative to platinum(II) ones. However, this problem has been circumvented by different synthetic strategies, most of them aimed at lowering this kinetic lability by coordination of the metal by polydentate or bulky ligands, yielding compounds with interesting therapeutic properties, largely determined by the nature of the ligands. ${ }^{7-12}$ Kovala-Demertzi and co-workers ${ }^{13}$ published an interesting study in which the substitution of a hydrogen for a methyl group in a bulky ligand has turned a biologically inactive compound into an active one. This shows that there is still much to be understood at the molecular level to unveil the physico-chemical phenomena that determine the behaviour of these metal-based compounds in living systems - their

\footnotetext{
${ }^{a}$ Unidade de I\&D “Química-Física Molecular”, Departamento de Química, Universidade de Coimbra, P-3004 535 Coimbra, Portugal.

E-mail: sonia.mfiuza@gmail.com; Fax: +351-239-826541; Tel: +351-239-826541

${ }^{b}$ ISIS Facility, SFTC Rutherford Appleton Laboratory, Chilton, Didcot, OX 11 OQX, UK

${ }^{c}$ Departamento de Ciências da Vida, P-3000 456, Universidade de Coimbra, Coimbra, Portugal

$\dagger$ Electronic supplementary information (ESI) available. See DOI: 10.1039/ c5nj01088h
}

structure-activity relationships (SARs) being of paramount importance. $\operatorname{Pd}($ II) complexes are particularly interesting compounds to perform SAR's studies, as the effect of the ligand on their biological activity is generally more pronounced than for their Pt(II) counterparts.

The present study focuses on a polynuclear $\operatorname{Pd}(\mathrm{II})$ chelate with a biogenic polyamine (spermine) $-\left\{\mu-\left\{N, N^{\prime}\right.\right.$-bis [(3-amino- $\left.\kappa N\right)$ propyl]butane-1,4-diamine- $\left.\kappa N: \kappa N^{\prime}\right\}$ tetrachloro-dipalladium (II), $\mathrm{Pd}_{2}$-Spm (Fig. 1A). ${ }^{14}$

This complex was shown to display interesting antiproliferative properties against cancer cells, ${ }^{15,16}$ although it presents a quite different chemical composition and structure from the array of active $\mathrm{Pd}(\mathrm{II})$ compounds reported in the literature to date. An understanding of the SARs determining this type of compound's activity is fundamental for interpreting the biochemical mechanisms underlying their biological effect (e.g. cytotoxicity), thus allowing a rational design of new Pd-based anticancer drugs. Vibrational spectroscopy has proven to be one of the most powerful techniques for performing conformational studies in biologically relevant molecules (including inorganic compounds). Inelastic neutron scattering (INS) spectroscopy is particularly well suited to study materials containing hydrogen atoms, since the scattering cross-section for hydrogen $\left({ }^{1} \mathrm{H}\right)$ (about 80 barns) is considerably larger than for most other elements (at most ca. 5 barns). The neutron scattering cross-section of an element is a characteristic of each isotope and independent of the chemical environment. During the scattering event, a fraction of the incoming neutron energy can be used to cause vibrational excitation, and the vibrational modes with the largest hydrogen displacements will dominate the spectrum. Therefore, INS can be especially important in solids in which the molecular units 


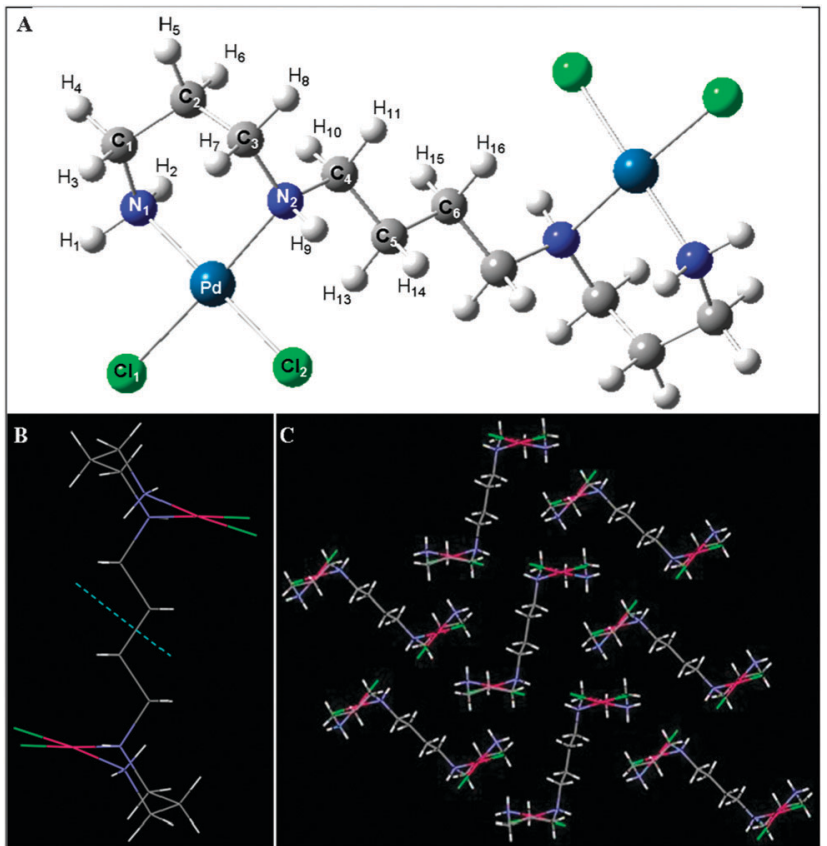

Fig. 1 (A) Optimized structure (LANL2DZ/6-31G*) for the $\mathrm{Pd}_{2}-\mathrm{Spm}$ isolated molecule and the atom numbering scheme. (B) $\mathrm{X}$-ray structure for $\mathrm{Pd}_{2}$-Spm (preferred conformation in the solid state with the inversion center highlighted by the blue dashed line). (C) Crystal structure arrangement for $\mathrm{Pd}_{2}-\mathrm{Spm}$.

are linked together by close hydrogen contacts, with the lowestfrequency vibrations expected to be most affected. Combining experimental vibrational spectroscopy results with quantum mechanical calculated data allows a deeper understanding of the correlation between the system's molecular properties (structure and conformation) and the corresponding spectra.

In this study, quantum mechanical calculations were carried out for $\mathrm{Pd}_{2}$-Spm at the DFT level, since this approach has been shown to deliver accurate results for this type of system. ${ }^{17-19}$ A theoretical model previously reported by the authors for a mononuclear Pd(II) compound bearing non-chelating ligands ${ }^{17}$ was presently evaluated because of its suitability for the highly flexible polynuclear polydentate chelate $\mathrm{Pd}_{2}$-Spm. The accuracy of the calculated results was assessed by comparison with the experimental data available on this chelate - both studies reported $\mathrm{X}$-ray structural information ${ }^{14}$ and the vibrational results gathered in this work.

\section{Experimental}

\subsection{Synthesis of $\mathbf{P d}_{2}-\mathrm{Spm}$}

Potassium tetrachloropalladate(II) $\left(\mathrm{K}_{2} \mathrm{PdCl}_{4}, 98 \%\right)$ and spermine ( $\geq 97 \%$ ) were acquired from Sigma (Sintra, Portugal) and used without further purification.

The synthesis of $\mathrm{Pd}_{2}$-Spm was carried out following an optimized procedure based on the published synthetic route. ${ }^{14}$ Briefly, $2 \mathrm{mmol}$ of $\mathrm{K}_{2} \mathrm{PdCl}_{4}$ were dissolved in a minimal amount of water, and an aqueous solution containing $1 \mathrm{mmol}$ of spermine was added dropwise under continuous stirring for about $24 \mathrm{~h}$. Solid $\left(\mathrm{PdCl}_{2}\right)_{2}(\mathrm{Spm})$ was formed, which was filtered and washed with pure acetone. Upon drying in an oven at $40{ }^{\circ} \mathrm{C}$ overnight, yellow crystals were obtained.

Yield: $68 \%$. Elemental analysis was carried out at the Atlantic Microlab, Inc., Georgia, USA. Calculated - C: 21.56\%; H: 4.70\%; N: $10.06 \%$, Cl: $25.46 \%$ and Found: C: $21.22 \%$; H: 4.68\%; N: 9.60\%, Cl: $25.88 \%$.

\subsection{Vibrational spectroscopy}

Room-temperature Fourier transform Raman (FT-Raman) spectra were acquired using a Bruker RFS-100 Fourier transform Raman spectrometer, with near-infrared excitation provided by the $1064 \mathrm{~nm}$ line of a Nd:YAG laser. A laser power of $150 \mathrm{~mW}$ at the sample position was used. Each spectrum was the average of three repeated measurements of 150 scans at $2 \mathrm{~cm}^{-1}$ resolution.

Fourier transform infrared (FTIR) spectra at room temperature were recorded over the $400-4000 \mathrm{~cm}^{-1}$ region, with a Mattson 7000 FTIR spectrometer, using a globar source, a deuterated triglycine sulfate (DTGS) detector and potassium bromide pellets. Each spectrum was composed of 32 scans with $2 \mathrm{~cm}^{-1}$ resolution and triangular apodization.

The INS spectrum of the complex was obtained at the ISIS Pulsed Neutron Source of the STFC Rutherford Appleton Laboratory (United Kingdom), using the TOSCA spectrometer, an indirect geometry time-of-flight, high resolution ( $c a .1 .25 \%$ of the energy transfer), and broad range spectrometer. ${ }^{20}$ A crystalline sample of the complex (2-3 g) was wrapped in a $4 \times 4 \mathrm{~cm}$ aluminium foil sachet, which filled the beam, and placed in a thin walled aluminium can. To reduce the impact of the Debye-Waller factor on the observed spectral intensity, the sample was cooled to $c a$. $15 \mathrm{~K}$. Data were recorded in the energy range from 24 to $4000 \mathrm{~cm}^{-1}$ and converted to the conventional scattering law, $\mathrm{S}(Q, \nu)$ vs. energy transfer (in $\mathrm{cm}^{-1}$ ) through standard programs.

\subsection{Computational details}

All calculations were performed using the Gaussian 03W (G03W) package. ${ }^{21}$ Both isolated molecule and two-molecule geometry were fully optimized by the Berny algorithm using redundant internal coordinates. While the initial conformational study was carried out without symmetry constraints, once the best conformer was selected, subsequent calculations were subject to symmetry constraints ( $C_{\mathrm{i}}$ symmetry group). In all cases, vibrational frequency calculations were performed, at the same level of theory, to verify that the geometries corresponded to a real minimum in the potential energy surface (no negative eigenvalues) and to simulate the vibrational spectra.

Two approaches were used to describe the palladium atom: either by relativistic pseudopotentials developed by Hay and Wadt, ${ }^{22}$ in a double-zeta splitting scheme, as implemented in G03W (keyword $L A N L 2 D Z$ ) or by an all-electron (AE) contracted Gaussian basis set developed by Friedlander. ${ }^{23}$ The inclusion of a polarization function at the $\mathrm{Pd}$ atom, by augmenting the valence shell with an $f$-function $\left(\zeta_{\mathrm{Pd}}=1.472\right)$, was also tested in combination with LANL2DZ. ${ }^{24}$ For the non-metal atoms, several AE basis sets were tested: 6-31G*, 6-31G**, 6-31+G(2d) 
Table 1 Theoretical levels considered in this study, using the mPW1PW functional

\begin{tabular}{|c|c|c|}
\hline \multirow[b]{2}{*}{ System } & \multicolumn{2}{|l|}{ Basis set } \\
\hline & $\operatorname{Pd}(\mathrm{II})^{a}$ & Non-heavy atoms ${ }^{b}$ \\
\hline Two-molecule model & LANL2DZ & $6-31 G^{*}$ \\
\hline \multirow[t]{10}{*}{ Isolated molecule } & $\mathrm{AE}$ & $6-31 G^{*}$ \\
\hline & $\mathrm{AE}$ & $6-31 \mathrm{G}^{* *}$ \\
\hline & $\mathrm{AE}$ & $6-31+G(2 d f)$ \\
\hline & $\mathrm{AE}$ & $6-31 \mathrm{G}^{* *}(\mathrm{H})$ \\
\hline & & $6-31 G^{*}(\mathrm{C})$ \\
\hline & & $6-31+\mathrm{G}(2 \mathrm{~d})(\mathrm{N})$ \\
\hline & & $6-31+G(2 \mathrm{df})(\mathrm{Cl})$ \\
\hline & $\mathrm{AE}$ & $6-31 \mathrm{G}^{* *}(\mathrm{H})$ \\
\hline & & $6-31+G(2 d)(C, N)$ \\
\hline & & $6-31+\mathrm{G}(2 \mathrm{df})(\mathrm{Cl})$ \\
\hline
\end{tabular}

${ }^{a} \mathrm{AE}$ stands for the all electron basis set of Friedlander ${ }^{23}$ used at the $\mathrm{Pd}(\mathrm{II})$ ion. ${ }^{b}$ Basis sets used generally or specifically on each atom as specified in mix1 and mix2.

and $6-31+\mathrm{G}(2 \mathrm{df}$ ) (as defined in G03W), either alone or simultaneously in distinct combinations schemes for different atoms (mix 1 and mix 2), as described in Table 1. Natural bond orbital (NBO) analysis was also performed. The basis sets were tested at the DFT level, using the mPW1PW method which comprises a modified version of the exchange term of Perdew-Wang and the Perdew-Wang 91 correlation functional, ${ }^{25,26}$ which has been shown to be advantageous over other DFT functionals for both linear amine ligands and their $\mathrm{Pt}(\mathrm{II}) / \mathrm{Pd}(\mathrm{II})$ complexes. ${ }^{17,18,27}$ The B97D DFT, which includes semi-empirical corrections for dispersion, was also tested. ${ }^{28}$ In order to account for the basis set superposition error (BSSE) in the two-molecule model calculation, geometries were optimized within the scheme of Boys-Bernardi ${ }^{29}$ (as implemented in G03W, by the keyword COUNTERPOISE). The SCRF (self-consistent reaction field) calculations were performed considering the aqueous solution $(\varepsilon=78.39)$ using default parameters for the UAHF (united atom topological model) radii model. ${ }^{21}$

\section{Results and discussion}

\subsection{Conformational analysis}

The reported X-ray structure for the $\mathrm{Pd}_{2}$-Spm molecule ${ }^{14}$ (Fig. 1) comprises both $\mathrm{Pd}(\mathrm{dap}) \mathrm{Cl}_{2}$ units (dap = 1,3-diaminopropane, $\left.\mathrm{H}_{2} \mathrm{~N}\left(\mathrm{CH}_{2}\right)_{3} \mathrm{NH}_{2}\right)$ in a relative trans arrangement. The chelate ring assumes a chair conformation, while the central putrescinelike moiety has an all-trans geometry. Careful inspection of this crystalline lattice structure (Fig. 1C) suggests the formation of intermolecular $\mathrm{H}$-bonds between the $\operatorname{Pd}($ dap $) \mathrm{Cl}_{2}$ fractions of adjacent molecules, namely, $\mathrm{Cl}_{1} ; \mathrm{Cl}_{2} \cdots \mathrm{H}_{1}, \mathrm{H}_{2}\left(\mathrm{~N}_{1}\right)$ and $\mathrm{Cl}_{2} \cdots \mathrm{H}_{9}\left(\mathrm{~N}_{2}\right)$, as well as a $\mathrm{Cl}_{1} \cdots \mathrm{H}_{10}\left(\mathrm{C}_{4}\right)$ interaction. The more hydrophobic methylene groups should not be involved in this type of close contact.

Taking the determined X-ray geometry as the starting point, a rotational conformational analysis was performed for the $\mathrm{Pd}_{2}$-Spm isolated molecule (Fig. S1 of the ESI $\dagger$ ), considering a previous work on the cDDPd mononuclear complex. ${ }^{17}$ We were interested in testing the relative stability of different cis/trans conformations (regarding the two metal centres relative to each other), all-trans and non-trans configurations of the amine linker and the presence or absence of co-planarity of the metal centre relative to the central amine linker. The minimum energy conformer obtained for $\mathrm{Pd}_{2}$-Spm differs significantly from the reported X-ray structure. As the present work aims to understand the properties of a molecule in the solid state, this type of single molecule conformational study may not be adequate to accurately represent these large polynuclear systems, since the intermolecular interactions between neighbouring molecules in the crystal lattice (Fig. 1C) impact their structure to a much larger extent than for mononuclear complexes playing a non-negligible role on the maintenance of the overall chelate's conformation. The number of rotational conformers makes this type of study prohibitive for a system such as this one as it is too large and presents too many degrees of freedom.

In fact, taking the isomer present in the solid state, we screened it with the license-free program Avogadro ${ }^{30}$ (using a molecular mechanics universal force field (UFF)), which predicted 242 conformers. Twenty of them, among the ones with lowest energy, were chosen to perform a more thorough study (Fig. S1, $\mathrm{ESI} \dagger$ ) as we were interested mainly in testing the relative stability of cis/trans conformations (regarding the two metal centres relative to each other), all-trans and non-trans configurations of the amine linker and co-planarity regarding the metal centre relative to the central amine linker.

Although plane-wave calculations have been carried out by the authors ${ }^{31-34}$ to predict solid state arrangements, this type of approach is not easily accessible for this particular dinuclear chelate due to the large dimensions of the corresponding unit cell. In view of these limitations, and taking into account the aim of this study, to predict the properties of $\mathrm{Pd}_{2}-\mathrm{Spm}$ in the solid state, the lowest-energy conformer found for the isolated molecule (conformer 1, Fig. S1, ESI $\dagger$ ) was not considered in further analysis, but rather the optimized $\mathrm{Pd}_{2}$-Spm isolated molecule that matches the X-ray data (Fig. 1A) was used.

\subsection{Structural analysis}

The single molecule of $\mathrm{Pd}_{2}$-Spm taken from the X-ray file, which was previously optimized without symmetry constraints (conformer 5, Fig. S1, ESI $\dagger$ and Fig. 1A), was then re-optimized under symmetry constraints $\left(C_{\mathrm{i}}\right.$ symmetry group), yielding the structural parameters shown in Table 2. The differences between the experimental and calculated values ( $\Delta$-values), and the corresponding overall errors ( $\Delta \Delta$-values), calculated as previously described for cisplatin, ${ }^{18}$ are also shown. In general, the larger deviations from the experimental values are verified for the $\mathrm{Pd}$ (dap) $\mathrm{Cl}_{2}$ moiety. It was hypothesized that these could be mainly due to (i) poor description of the metal centre and/or (ii) neglecting the intermolecular interactions present in the crystal lattice.

Considering hypothesis (i), the LANL2DZ ECP was augmented with an $f$-polarization function at the Pd centre and the all-electron basis set of Friedlander ${ }^{23}$ was tested on the metal ion. While augmenting the Pd valence shell did not lead to a significant 
Table 2 Experimental and calculated (mPW1PW) structural parameters for $\mathrm{Pd}_{2}$-Spm, at different theoretical levels

\begin{tabular}{|c|c|c|c|c|c|c|c|c|c|c|c|c|c|c|c|}
\hline \multirow[b]{2}{*}{$\begin{array}{l}\text { Structural } \\
\text { parameter }\end{array}$} & \multirow[b]{2}{*}{$\operatorname{Exp}^{a}$} & \multicolumn{14}{|l|}{ Theory level } \\
\hline & & $\begin{array}{l}\text { LANL2DZ/ } \\
6-31 G^{*}\end{array}$ & $\Delta^{b}$ & $\underset{6-31 \mathrm{G}^{*}}{\mathrm{AE} /}$ & $\Delta^{b}$ & $\underset{6-31 \mathrm{G}^{* *}}{\mathrm{AE} /}$ & $\Delta^{b}$ & $\begin{array}{c}\mathrm{AE} / \\
6-31 \mathrm{G}+(2 \mathrm{~d})\end{array}$ & $\Delta^{b}$ & $\begin{array}{l}\mathrm{AE} / \\
\operatorname{mix} 1\end{array}$ & $\Delta^{b}$ & $\begin{array}{l}\mathrm{AE} / \\
\operatorname{mix} 2\end{array}$ & $\Delta^{b}$ & $\begin{array}{c}\text { SCRF } \\
\text { LANL2DZ/6-31G* }\end{array}$ & $\Delta^{b}$ \\
\hline \multicolumn{16}{|c|}{ Bond length/pm } \\
\hline $\mathrm{Pd}-\mathrm{N}_{1}$ & 202.2 & 208.4 & 6.2 & 205.3 & 3.1 & 205.3 & 3.1 & 205.0 & 2.8 & 204.7 & 2.5 & 206.1 & 3.9 & 206.4 & 4.2 \\
\hline $\mathrm{Pd}-\mathrm{N}_{2}$ & 204.1 & 209.8 & 5.7 & 205.7 & 1.6 & 205.2 & 1.1 & 205.5 & 1.4 & 205.1 & 1.0 & 205.5 & 1.4 & 208.1 & 4.0 \\
\hline $\mathrm{Pd}-\mathrm{Cl}_{1}$ & 231.6 & 231.7 & 0.1 & 232.8 & 1.2 & 227.9 & -3.7 & 233.0 & 1.4 & 232.4 & 0.8 & 228.7 & -2.9 & 235.7 & 4.1 \\
\hline $\mathrm{Pd}-\mathrm{Cl}_{2}$ & 231.4 & 232.2 & 0.8 & 233.8 & 2.4 & 229.2 & -2.2 & 233.9 & 2.5 & 233.3 & 1.9 & 230.6 & -0.8 & 235.4 & 4.0 \\
\hline $\mathrm{N}_{1}-\mathrm{C}_{1}$ & 148.5 & 147.8 & -0.7 & 147.2 & -1.3 & 147.1 & -1.4 & 147.2 & -1.3 & 147.3 & -1.2 & 147 & -1.5 & 147.7 & -0.8 \\
\hline $\mathrm{N}_{2}-\mathrm{C}_{3}$ & 148.7 & 147.5 & -1.2 & 147.1 & -1.6 & 147.3 & -1.4 & 147.0 & -1.7 & 147.1 & -1.6 & 146.9 & -1.8 & 148.4 & -0.3 \\
\hline $\mathrm{C}_{1}-\mathrm{C}_{2}$ & 150.6 & 152.4 & 1.8 & 152.5 & 1.9 & 152.4 & 1.8 & 152.5 & 1.9 & 152.5 & 1.9 & 152.3 & 1.7 & 151.8 & 1.2 \\
\hline $\mathrm{C}_{2}-\mathrm{C}_{3}$ & 151.8 & 152.7 & 0.9 & 152.8 & 1.0 & 152.6 & 0.8 & 152.8 & 1.0 & 152.8 & 1.0 & 152.6 & 0.8 & 152.2 & 0.4 \\
\hline $\mathrm{C}_{4}-\mathrm{C}_{5}$ & 152.1 & 152.1 & 0.0 & 152.3 & 0.2 & 152.1 & 0.0 & 152.3 & 0.2 & 152.3 & 0.2 & 152.0 & -0.1 & 152.0 & -0.1 \\
\hline $\mathrm{C}_{5}-\mathrm{C}_{6}$ & 153.3 & 152.6 & -0.7 & 151.5 & -1.8 & 152.4 & -0.9 & 151.5 & -1.8 & 151.5 & -1.8 & 152.0 & -1.3 & 152.7 & -0.6 \\
\hline $\mathrm{N}_{2}-\mathrm{C}_{4}$ & 148.8 & 147.8 & 1.0 & 147.8 & -1.0 & 147.4 & -1.4 & 147.7 & -1.1 & 147.8 & -1.0 & 147.0 & -1.8 & 148.2 & -0.6 \\
\hline \multicolumn{16}{|l|}{ Angles/ ${ }^{\circ}$} \\
\hline $\mathrm{Cl}_{1}-\mathrm{Pd}-\mathrm{Cl}_{2}$ & 93.9 & 96.3 & 2.4 & 99.2 & 5.3 & 97.0 & 3.1 & 99.5 & 5.6 & 99.1 & 5.2 & 97.7 & 3.8 & 93.5 & -0.4 \\
\hline $\mathrm{N}_{1}-\mathrm{Pd}-\mathrm{N}_{2}$ & 90.3 & 92.0 & 1.7 & 91.9 & 1.6 & 91.8 & 1.5 & 92.1 & 1.8 & 92 & 1.7 & 91.7 & 1.4 & 89.7 & -0.6 \\
\hline $\mathrm{N}_{1}-\mathrm{Pd}-\mathrm{Cl}_{1}$ & 88.5 & 85.5 & -3.0 & 84.3 & -4.2 & 85.5 & -3.0 & 84.0 & -4.5 & 84.3 & -4.2 & 85.6 & -2.9 & 87.8 & -0.7 \\
\hline $\mathrm{N}_{2}-\mathrm{Pd}-\mathrm{Cl}_{2}$ & 87.5 & 86.1 & -1.4 & 84.5 & -3.0 & 85.7 & -1.8 & 84.2 & -3.3 & 84.5 & -3.0 & 85.0 & -2.5 & 89.0 & 1.5 \\
\hline $\mathrm{Pd}-\mathrm{N}_{1}-\mathrm{C}_{1}$ & 114.8 & 113.8 & -1.0 & 108.5 & -6.3 & 113.2 & -1.6 & 108.5 & -6.3 & 108.5 & -6.3 & 113.1 & -1.7 & 114.3 & -0.5 \\
\hline $\mathrm{Pd}-\mathrm{N}_{2}-\mathrm{C}_{3}$ & 113.9 & 111.8 & -2.1 & 112.4 & -1.5 & 111.9 & -2.0 & 112.4 & -1.5 & 112.4 & -1.5 & 112.5 & -1.4 & 111.6 & -2.3 \\
\hline $\mathrm{Pd}-\mathrm{N}_{2}-\mathrm{C}_{4}$ & 113.0 & 115.5 & 2.5 & 112.1 & -0.9 & 115.3 & 2.3 & 112.1 & -0.9 & 112.1 & -0.9 & 114.1 & 1.1 & 114.1 & 1.1 \\
\hline $\mathrm{N}_{1}-\mathrm{C}_{1}-\mathrm{C}_{2}$ & 110.5 & 112.5 & 2.0 & 112.3 & 1.8 & 112.2 & 1.7 & 112.3 & 1.8 & 112.2 & 1.7 & 112.7 & 2.2 & 112.3 & 1.8 \\
\hline $\mathrm{N}_{2}-\mathrm{C}_{3}-\mathrm{C}_{2}$ & 114.3 & 114.5 & 0.2 & 114.4 & 0.1 & 114.1 & -0.2 & 114.3 & 0.0 & 114.3 & 0.0 & 114.2 & -0.1 & 114.7 & 0.4 \\
\hline $\mathrm{C}_{1}-\mathrm{C}_{2}-\mathrm{C}_{3}$ & 115.7 & 115.9 & 0.2 & 116.4 & 0.7 & 115.8 & 0.1 & 116.4 & 0.7 & 116.4 & 0.7 & 116.0 & 0.3 & 114.9 & -0.8 \\
\hline $\mathrm{C}_{3}-\mathrm{N}_{2}-\mathrm{C}_{4}$ & 113.0 & 113.7 & 0.7 & 115.1 & 2.1 & 113.9 & 0.9 & 115.2 & 2.2 & 115.0 & 2.0 & 114.2 & 1.2 & 112.9 & -0.1 \\
\hline $\mathrm{N}_{2}-\mathrm{C}_{4}-\mathrm{C}_{5}$ & 112.3 & 112.3 & 0.0 & 109.6 & -2.7 & 111.7 & -0.6 & 109.6 & -2.7 & 109.6 & 2.7 & 112.0 & -0.3 & 112.4 & 0.1 \\
\hline $\mathrm{C}_{4}-\mathrm{C}_{5}-\mathrm{C}_{6}$ & 111.3 & 111.2 & 0.1 & 113.0 & 1.7 & 111.5 & 0.2 & 113.1 & 1.8 & 113.0 & 1.7 & 111.3 & 0.0 & 111.2 & -0.1 \\
\hline$\Delta \Delta$ & & & 1.5 & & 2.0 & & 1.5 & & 2.1 & & 1.9 & & 1.5 & & 1.3 \\
\hline
\end{tabular}

change (results not shown), the use of an $\mathrm{AE}$ basis set at the Pd ion caused clear changes in the complex's structural parameters. From analysis of Table 2, it is evident that the use of an $\mathrm{AE}$ basis set on $\mathrm{Pd}(\mathrm{II})$ greatly improves the prediction of the $\mathrm{Pd}-\mathrm{N}$ bond length, which had been previously overestimated by all theoretical approaches. However, this leads to a worsening of the $\mathrm{Pd}-\mathrm{Cl}$ bond lengths (as well as of some bond angles involving chlorine) in the following order: for the $\mathrm{Pd}-\mathrm{Cl}$ bond, LANL2DZ/6-31G* $>\mathrm{AE} / \mathrm{mix} 1>\mathrm{AE} / 6-31 \mathrm{G}^{*} \sim \mathrm{AE} / \mathrm{mix} 2>\mathrm{AE} /$ $6-31 \mathrm{G}+(2 \mathrm{~d})>\mathrm{AE} / 6-31 \mathrm{G}^{* *}$; for the Cl-Pd-Cl angle, LANL2DZ/ $6-31 \mathrm{G}^{*}>\mathrm{AE} / 6-31 \mathrm{G}^{* *}>\mathrm{AE} / \mathrm{mix} 2>\mathrm{AE} / \mathrm{mix} 1 \sim \mathrm{AE} / 6-31 \mathrm{G}^{*}>$ $\mathrm{AE} / 6-31 \mathrm{G}+(2 \mathrm{~d})$; for the $\mathrm{Cl}-\mathrm{Pd}-\mathrm{N}$ angle, LANL2DZ/6-31G* $>$ $\mathrm{AE} / 6-31 \mathrm{G}^{* *}>\mathrm{AE} / \mathrm{mix} 2>\mathrm{AE} / \mathrm{mix} 1 \sim 6-31 \mathrm{G}^{*}>\mathrm{AE} / 6-31 \mathrm{G}+(2 \mathrm{~d})$. Interestingly, the addition of a polarization function to the hydrogen atom $\left(\mathrm{AE} / 6-31 \mathrm{G}^{*} \rightarrow \mathrm{AE} / 6-31 \mathrm{G}^{* *}\right)$ leads to a better overall agreement relative to the experimental values of the $\mathrm{Cl}-\mathrm{Pd}-\mathrm{Cl}$ and $\mathrm{N}-\mathrm{Pd}-\mathrm{Cl}$ angles, which is probably be due to a better description of the neighbouring molecular groups bearing hydrogens. However, including higher polarization functions on the non-hydrogen atoms $(\mathrm{AE} / 6-31+\mathrm{G}(2 \mathrm{~d}))$ did not lead to an enhancement of the overall $\Delta \Delta$ values. Coupling the $\mathrm{AE}$ basis set tested for $\mathrm{Pd}(\mathrm{II})$ with a combination of different $\mathrm{AE}$ basis sets for the remaining atoms (mix1 or mix2) yielded better $\Delta \Delta$ values but did not solve the problem entirely. While mix1, which involves more extensive basis sets for the chlorine and nitrogen atoms (Table 1), led to a significant improvement of the $\mathrm{Pd}-\mathrm{Cl}$ bond length, it did not produce more accurate values for the bond angles. In turn, while mix2, which extends the improvement of the basis set to the carbon, chlorine and nitrogen atoms (Table 1), yields better $\Delta$ values for the angles, it worsens some of the bond lengths.

Regarding hypothesis (ii), calculations for a two-molecule species (Fig. S2, ESI $\dagger$ ) based on the X-ray structure reported for the complex were performed to verify if accounting for intermolecular interactions could improve the results. Considering this model led to an improvement of the calculated $\mathrm{Pd}-\mathrm{N}$ bond length, at the cost of a worsening of the values for the $\mathrm{Pd}-\mathrm{Cl}$ bond (Table S1, ESI $\dagger$ ). However, although the bond angles involving the metal centre were greatly improved, the overall error was not much lower than that obtained for the isolated molecule. The reason for this probably lies on the fact that two $\mathrm{Pd}_{2}$-Spm molecules are not enough to represent all the intermolecular interactions occurring in the solid lattice, where one $\mathrm{Pd}_{2}$-Spm entity is surrounded by six neighbouring molecules (Fig. 1C). Accounting for a six-molecule model using the present theoretical approach is, however, not feasible. A calculation for the two-molecule structure was also performed with the new B97D DFT, which accounts for dispersion corrections allowing a better description of the intermolecular interactions, but without significant improvement in the results (not shown). Although the structural experimental parameters are given for the solid state, SCRF results were also used to assess intermolecular interactions, not between similar molecules, but with other molecules such as the ones occurring when simulating an aqueous solution. The results 
gathered in Table 2 show that, interestingly, SCRF results are the ones that present the lowest bond lengths deviations obtained for the linking amine fragment $\mathrm{N}_{1}-\mathrm{C}_{1}-\mathrm{C}_{2}-\mathrm{C}_{3}-\mathrm{N}_{2}$ and $\mathrm{N}_{2}-\mathrm{C}_{4}$. It also presents the lowest deviation values for the $\mathrm{Cl}_{1}-\mathrm{Pd}-\mathrm{Cl}_{2}, \mathrm{~N}_{1}-\mathrm{Pd}-\mathrm{N}_{2}$ and $\mathrm{Cl}_{1}-\mathrm{Pd}-\mathrm{N}_{1}$ angles, the ones more prone to establish intermolecular interactions. The reason for an improvement of these results when compared to the twomolecule structures, even when comparing different physical states, may be the limitation of considering only a two-molecule system instead of a larger one with at least two layers of molecules below and above. These results shed some light and hope on a very accurate prediction when plane-wave tools become available for the study of these compounds.

The theoretical estimate of the chelate's structural parameters is of the utmost importance for the prediction of reliable SARs for the complex. When comparing the experimental bond lengths for different compounds of the same type, it is interesting to verify that within $\mathrm{Pd}_{2}-\mathrm{Spm}$, the $\mathrm{Pd}-\mathrm{N}$ bonds (203.2 pm average value, Table 2) are shorter relative to the parent mononuclear compound cDDPd $(206.0 \mathrm{pm}),{ }^{35}$ while the $\mathrm{Pd}-\mathrm{Cl}$ ones are longer (231.5 pm vs. $227.5 \mathrm{pm}$ ). ${ }^{35}$ Natural bond orbital (NBO) calculations through the calculated Wiberg bond indices - an indicator that reflects the strength of the bond - also predict this trend, which is interestingly correlated with the biological activity of the complexes involved (Fig. 2). In fact, regarding the human breast cell line MDA-MB-231, the $\mathrm{IC}_{50}$ obtained at $24 \mathrm{~h}$ are for $\mathrm{cDDPd} \geq$ $100 \mu \mathrm{M}$, for $\mathrm{Pd}\left(\right.$ dap) $\mathrm{Cl}_{2}>100 \mu \mathrm{M}$ and for $\mathrm{Pd}_{2}-\mathrm{Spm}=4.7 \mu \mathrm{M}$.

The mode of action of this type of metal-based compound is recognized to be through interaction, via covalent binding, with DNA. ${ }^{36,37}$ Although the exact mechanism for Pd(II) complexes is not as well established as for their Pt(II) analogues, they are expected to have a rather similar behaviour due to their similar chemical characteristics. The anticancer properties of the wellknown chemotherapeutic drug cisplatin relies on the binding of Pt(II) to the nitrogen $\left(\mathrm{N}^{7}\right)$ of the DNA bases. ${ }^{36-38}$ This step must be preceded by an intracellular drug activation process through aquation, which involves the hydrolysis of the chlorine ligands. Accordingly, it is expected that the DNA binding ability of these amine-based $\mathrm{Pd}$ (II) complexes increases with weakening of the $\mathrm{Pd}-\mathrm{Cl}$ bonds, as evidenced in Fig. 2. Although more systems are needed for an unequivocal and reliable correlation, these results prompt the investigation of this possible correlation and stress the importance of this type of study, even if in the solid state.

\subsection{Vibrational analysis}

$\mathrm{Pd}_{2}$-Spm has 132 vibrational modes, 66 of $A_{\mathrm{u}}$ symmetry (infrared active) and 66 bearing $A_{\mathrm{g}}$ symmetry (Raman active). All the modes are INS active, since there are no selection rules for this non-optical vibrational spectroscopy technique (Fig. 3).

The assignment of the vibrational spectra of $\mathrm{Pd}_{2}-\mathrm{Spm}$, as well as the calculated wavenumber at the LANL2DZ/6-31G* theory level, are presented in Table 3. It has been shown previously that the small enhancement obtained with higher theory levels is not worth the associated computational cost. ${ }^{17,18}$ Some vibrational modes (as well as the corresponding nomenclature used throughout the text) are schematically represented in Fig. 4.

As the metal units are linked by the aliphatic amine spermine, some low frequency vibrations are similar to the reported LAM and TAM modes previously assigned for this polyamine. ${ }^{40,41}$ However, they were given alternative designations in this work since Pd-coordinated Spm does not constitute a free "linear bead system”, as illustrated in Fig. 4.

The inspection of Fig. 3 allows us to determine the importance and complementarity of the different techniques used. Raman spectroscopy features more intense $\mathrm{CH}_{2}$ stretching bands and also presents more prominent bands regarding the metal atom centres. In addition, the different bands from the organic parts of the molecule are not quite well resolved, appearing broad and overlapped. Nonetheless, the resolution of the band relative to the metal centre using the Raman technique allows us to distinguish the different vibrational frequencies, particularly for the $\mathrm{Pd}-\mathrm{N}$ bond. As the environment of $\mathrm{Pd}-\mathrm{N}_{1}$ is different from $\mathrm{Pd}-\mathrm{N}_{2}$, these modes are not degenerate and it is possible to identify 4 bands for the $\nu \mathrm{Pd}-\mathrm{N}$ vibration instead of 2 bands if their environment was the same, i.e., having a symmetrical centre.
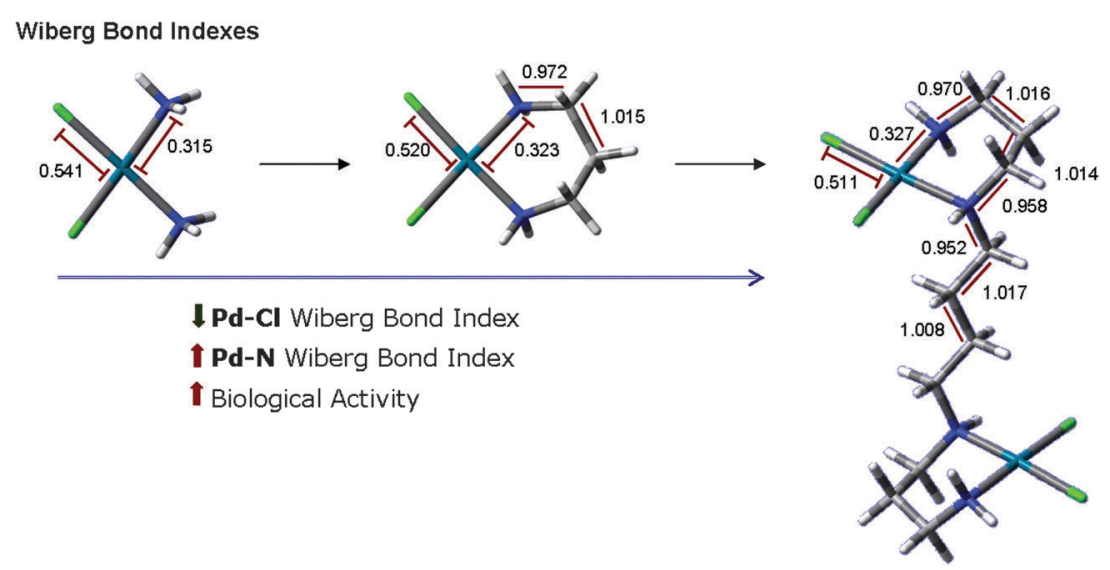

Fig. 2 Variation of Wiberg bond indices (WBI) for three different Pd(॥) complexes: cDDPd (cis-diamminodichloropalladium(II)), Pd(dap)Cl2 (1,3-diamminopropane-dichloropalladium(II)) and $\mathrm{Pd}_{2}-\mathrm{Spm}\left(\left\{\mu-\left\{N, N^{\prime}\right.\right.\right.$-bis $\left[(3\right.$-amino- $\kappa N)$ propyl]butane-1,4-diamine- $\left.\left.\kappa N: \kappa N^{\prime}\right\}\right\}$ tetrachloro-dipalladium (II)). (White - $\mathrm{H}$; Grey - C; Blue - N; Green - Cl; Cyan - Pd(II)). IC 50 values for the MDA-MB-231 cell line at $24 \mathrm{~h}$ are $\geq 100 \mu \mathrm{M},>100 \mu \mathrm{M}$ and $4.7 \mu \mathrm{M}$. 


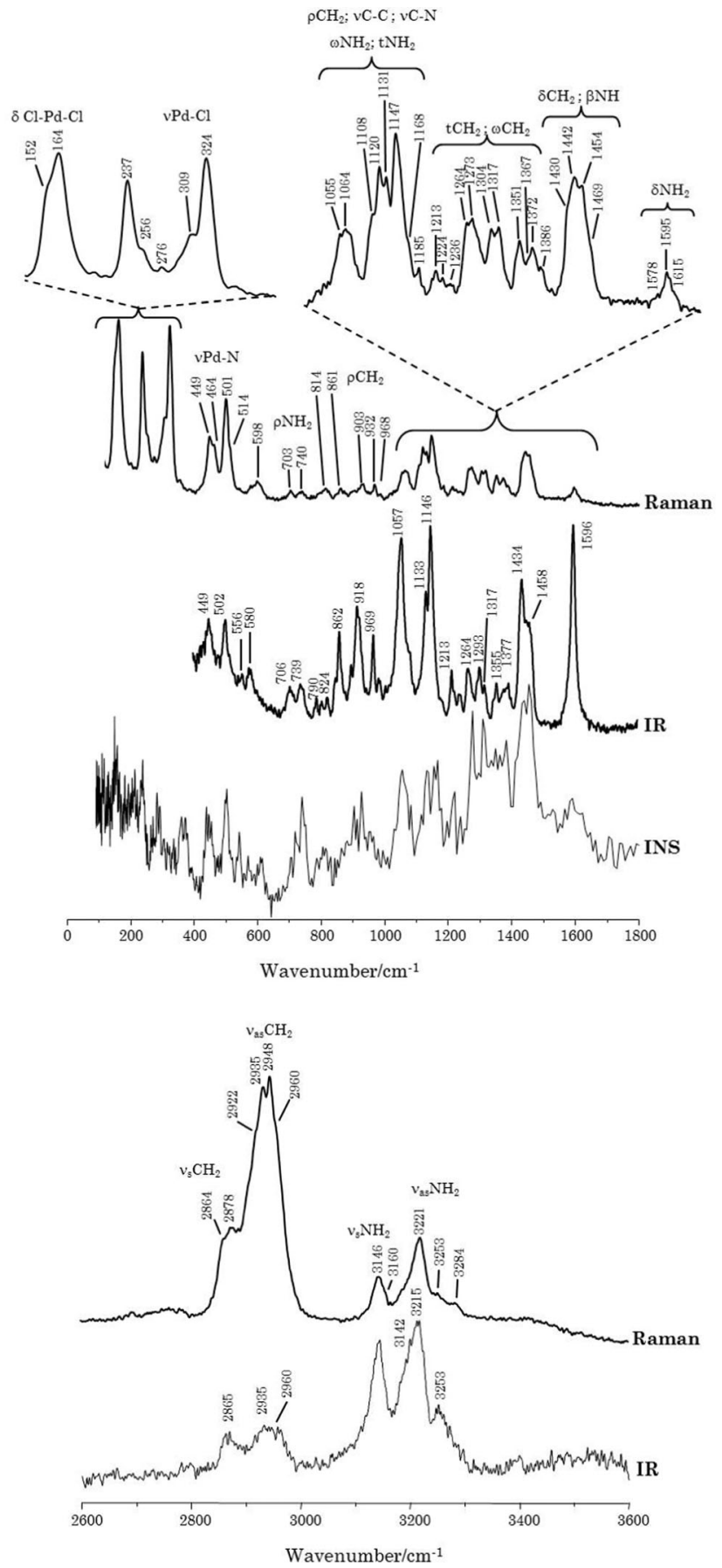

Fig. 3 Experimental vibrational spectra (Raman, IR and INS) for $\mathrm{Pd}_{2}-\mathrm{Spm}$.

This feature is not as clear when using the other vibrational techniques. IR and INS bands in turn appear much more defined in the region of $400-1800 \mathrm{~cm}^{-1}$ allowing the detection of a higher number of vibrational modes. Particularly important and characteristic of the IR technique is the very intense and well defined deformation band of $\mathrm{NH}_{2}$ at $1596 \mathrm{~cm}^{-1}$. When analysing the crystal structure packing unit, only one intermolecular hydrogen bond is available to the $\mathrm{NH}_{2}$ group $\left(\mathrm{N}_{1}\right) \mathrm{H}_{2}-\mathrm{Cl}_{2}$ (248.2 angstrom), and the next shortest contact for $\mathrm{NH}_{2}$ is a weak intramolecular interaction $\left(\mathrm{N}_{1}\right) \mathrm{H}_{1}-\mathrm{Cl}_{1}$ (268.7 angstrom).
This well-defined $\delta \mathrm{NH}_{2}$ band supports this occurrence as it is not as broad as the one expected for a group highly involved in strong hydrogen bonding. The INS technique in turn perfectly resolves the lower rocking modes of the $\mathrm{CH}_{2}$ and $\mathrm{NH}_{2}$ oscillators (almost imperceptible by Raman), as well as the ring structure torsion bands (almost absent from the IR and Raman spectra). These features stress the importance of using complementary vibrational techniques, especially for this type of complex, which tends to form intramolecular ring structures.

The vibrational modes of the spermine ligand were reasonably well predicted by the calculations, despite some deviations due to anharmonicity and/or intermolecular interactions. The major differences were verified for the modes involving the atoms directly bound to the metal atom, which cannot be justified in terms of anharmonicity since there is not a uniform pattern in the prediction of the wavenumbers. In order to determine whether this was a particular effect of this chelate, calculations were performed, at the same theory level (LANL2DZ/6-31G*), for a few other Pd(II) complexes with different amine ligands. The data thus gathered is shown in Table 4 as well as the scaling factor needed to match the calculated wavenumbers to the experimental ones. In every case, the theoretically predicted Pd-N stretching mode was found to be underestimated, while $\nu(\mathrm{Pd}-\mathrm{Cl})$ and $\nu\left(\mathrm{NH}_{3} / \mathrm{NH}_{2}\right)$ were overestimated. Hence, this lack of accordance is independent of the type of complex investigated, and the main issue probably remaining is the description of the modes involving the metal centre.

In addition, neither the $\mathrm{AE}$ approach to describe the metal centre nor the two-molecule model calculations led to a noticeable improvement of the corresponding vibrational modes. In fact, it was previously verified by the authors ${ }^{17}$ that an enhancement in the calculated structural parameters is not always accompanied by a corresponding improvement in the accuracy of the vibrational frequencies.

Although a straightforward comparison with the SCRF results (Table 3) cannot be performed, some interesting results can be observed. Actually, the vibrations relative to the stretching modes of $\mathrm{NH}_{2}$ and $\mathrm{CH}_{2}$ groups are greatly improved and comparable to the experimental values. Moreover, the symmetric stretching mode of $\mathrm{Pd}-\mathrm{N}$ is also improved, but not the antisymmetric one. A better agreement with the experimental value is also obtained for the $\mathrm{C}-\mathrm{N}-\mathrm{C}$ torsion of the ring structure. However, many other vibrational modes are poorly predicted, such as the $\mathrm{NH}_{2}$ and $\mathrm{CH}_{2}$ scissoring and most wagging, twisting and rocking modes of the $\mathrm{CH}_{2}$ groups. Moreover, many stretching vibrational modes for the $\mathrm{C}-\mathrm{C}$ and $\mathrm{C}-\mathrm{N}$ bonds fail to be predicted, as well as the $\nu(\mathrm{Pd}-\mathrm{Cl})$ ones. Nonetheless, the improvement obtained for the groups expected to be strongly involved in intermolecular interactions should be of reference for future studies on this type of systems.

\section{Conclusions}

In the present work, a complete vibrational study of a dinuclear $\operatorname{Pd}($ II) complex displaying a promising antiproliferative activity 
Table 3 Experimental (INS, Raman, FTIR) and calculated (LANL2DZ/6-31G*) vibrational wavenumber $\left(\mathrm{cm}^{-1}\right)$ for Pd $\mathrm{Pd}_{2}-\mathrm{Spm}$ (isolated molecule in gas phase and simulated aqueous solution (SCRF))

\begin{tabular}{|c|c|c|c|c|c|c|c|c|}
\hline \multicolumn{3}{|c|}{ Experimental } & \multirow[b]{2}{*}{ Calc. } & \multirow[b]{2}{*}{ Calc. (scaled) ${ }^{a}$} & \multirow[b]{2}{*}{ Calc. SCRF } & \multirow[b]{2}{*}{ Calc. SCRF (scaled) ${ }^{a}$} & \multirow[b]{2}{*}{ Sym. } & \multirow[b]{2}{*}{ Tentative assignment ${ }^{c}$} \\
\hline INS & Raman & FTIR & & & & & & \\
\hline & & 3253 & 3588 & $3408 / 3337^{b}$ & 3463 & $3290 / 3221^{b}$ & $A_{\mathrm{u}}$ & $\nu_{\mathrm{as}} \mathrm{NH}_{2}$ \\
\hline & 3221 & & 3588 & $3408 / 3337^{b}$ & 3462 & $3289 / 3220^{b}$ & $A_{\mathrm{g}}$ & $\nu_{\mathrm{as}} \mathrm{NH}_{2}$ \\
\hline & & 3215 & 3484 & $3309 / 3240^{b}$ & 3369 & $3200 / 3133^{b}$ & $A_{\mathrm{u}}$ & $\nu \mathrm{NH}$ \\
\hline & & & 3484 & $3309 / 3240^{b}$ & 3367 & $3198 / 3131^{b}$ & $A_{\mathrm{g}}$ & $\nu \mathrm{NH}$ \\
\hline & & 3142 & 3483 & $3309 / 3239^{b}$ & 3363 & $3195 / 3128^{b}$ & $A_{\mathrm{u}}$ & $\nu_{\mathrm{s}} \mathrm{NH}_{2}$ \\
\hline & 3146 & & 3483 & $3309 / 3239^{b}$ & 3362 & $3194 / 3127^{b}$ & $A_{\mathrm{g}}$ & $\nu_{\mathrm{s}} \mathrm{NH}_{2}$ \\
\hline & & & 3165 & 3006 & 3127 & 2970 & $A_{\mathrm{u}}$ & $\nu_{\mathrm{as}} \mathrm{CH}_{2(\text { ring })}$ \\
\hline & & & 3165 & 3006 & 3126 & 2969 & $A_{\mathrm{g}}$ & $\nu_{\mathrm{as}} \mathrm{CH}_{2 \text { (ring) }}$ \\
\hline & & & 3150 & 2992 & 3132 & 2975 & $A_{\mathrm{u}}^{\mathrm{s}}$ & $\nu_{\text {as }} \mathrm{CH}_{2 \text { (chain) }}$ \\
\hline & & 2960 & 3137 & 2980 & 3120 & 2964 & $A_{\mathrm{u}}^{\mathrm{u}}$ & $\nu_{\text {as }} \mathrm{CH}_{2 \text { (ring) }}$ \\
\hline & 2960 & & 3137 & 2980 & 3120 & 2964 & $A_{\mathrm{g}}$ & $\nu_{\mathrm{as}} \mathrm{CH}_{2 \text { (ring) }}$ \\
\hline \multirow[t]{15}{*}{2950} & 2948 & & 3130 & 2973 & 3128 & 2971 & $A_{\mathrm{g}}^{\circ}$ & $\nu_{\mathrm{as}} \mathrm{CH}_{2(\text { chain })}$ \\
\hline & 2935 & & 3126 & 2969 & 3043 & 2891 & $A_{\mathrm{g}}^{\mathrm{g}}$ & $\nu_{\text {as }} \mathrm{CH}_{2 \text { (ring) }}$ \\
\hline & & 2935 & 3126 & 2969 & 3042 & 2890 & $A_{\mathrm{u}}^{\mathrm{s}}$ & $\nu_{\mathrm{as}} \mathrm{CH}_{2 \text { (ring) }}$ \\
\hline & & & 3112 & 2956 & 3110 & 2954 & $A_{\mathrm{u}}$ & $\nu_{\text {as }} \mathrm{CH}_{2 \text { (chain) }}$ \\
\hline & 2922 & & 3110 & 2954 & 3094 & 2939 & $A_{\mathrm{g}}$ & $\nu_{\mathrm{as}} \mathrm{CH}_{2 \text { (chain) }}$ \\
\hline & & & 3092 & 2937 & 3063 & 2910 & $A_{\mathrm{u}}^{\mathrm{s}}$ & $\nu_{\mathrm{s}} \mathrm{CH}_{2 \text { (chain) }}$ \\
\hline & & & 3087 & 2932 & 3069 & 2915 & $A_{\mathrm{g}}$ & $\nu_{\mathrm{s}} \mathrm{CH}_{2(\text { ring })}$ \\
\hline & & & 3087 & 2932 & 3069 & 2915 & $A_{\mathrm{u}}^{\circ}$ & $\nu_{\mathrm{s}} \mathrm{CH}_{2 \text { (ring) }}$ \\
\hline & & & 3085 & 2930 & 3056 & 2903 & $A_{\mathrm{g}}$ & $\nu_{\mathrm{s}} \mathrm{CH}_{2 \text { (ring) }}$ \\
\hline & & & 3085 & 2930 & 3056 & 2903 & $A_{\mathrm{u}}^{s}$ & $\nu_{\mathrm{s}} \mathrm{CH}_{2 \text { (ring) }}$ \\
\hline & 2878 & & 3083 & 2929 & 3053 & 2900 & $A_{\mathrm{g}}$ & $\nu_{\mathrm{s}} \mathrm{CH}_{2 \text { (chain) }}$ \\
\hline & & & 3078 & 2924 & 2999 & 2849 & $A_{\mathrm{u}}$ & $\nu_{\mathrm{s}} \mathrm{CH}_{2 \text { (ring) }}$ \\
\hline & & & 3078 & 2924 & 2995 & 2845 & $A_{\mathrm{u}}$ & $\nu_{\mathrm{s}} \mathrm{CH}_{2 \text { (ring) }}$ \\
\hline & 2864 & & 3051 & 2898 & 3040 & 2888 & $A_{\mathrm{g}}$ & $\nu_{\mathrm{s}} \mathrm{CH}_{2 \text { (chain) }}$ \\
\hline & & 2865 & 3051 & 2898 & 3038 & 2886 & $A_{\mathrm{u}}$ & $\nu_{\mathrm{s}} \mathrm{CH}_{2(\text { chain })}$ \\
\hline \multirow[t]{4}{*}{1601} & 1595 & & 1699 & $1614 / 1580^{b}$ & 1661 & $1578 / 1545^{b}$ & $A_{\mathrm{g}}$ & $\delta \mathrm{NH}_{2}$ \\
\hline & & 1596 & 1699 & $1614 / 1580^{b}$ & 1660 & $1577 / 1544^{b}$ & $A_{\mathrm{u}}$ & $\delta \mathrm{NH}_{2}$ \\
\hline & & & 1539 & 1462 & 1532 & 1455 & $A_{\mathrm{u}}$ & $\delta \mathrm{CH}_{2 \text { (chain) }}$ \\
\hline & 1469 & & 1537 & 1460 & 1526 & 1450 & $A_{\mathrm{g}}$ & $\delta \mathrm{CH}_{2 \text { (chain) }}$ \\
\hline \multirow[t]{2}{*}{1457} & & 1458 & 1529 & 1452 & 1511 & 1435 & $A_{\mathrm{u}}^{\mathrm{s}}$ & $\delta \mathrm{CH}_{2 \text { (ring) }}$ \\
\hline & 1454 & & 1527 & 1450 & 1510 & 1434 & $A_{\mathrm{g}}$ & $\delta \mathrm{CH}_{2 \text { (ring) }}$ \\
\hline 1440 & & 1449 & 1524 & 1448 & 1507 & 1431 & $A_{\mathrm{u}}^{\mathrm{z}}$ & $\delta \mathrm{CH}_{2 \text { (ring) }}$ \\
\hline & 1442 & & 1523 & 1447 & 1506 & 1431 & $A_{\mathrm{g}}$ & $\delta \mathrm{CH}_{2 \text { (ring) }}$ \\
\hline & & & 1511 & 1435 & 1509 & 1433 & $A_{\mathrm{u}}^{\mathrm{s}}$ & $\delta \mathrm{CH}_{2 \text { (ring) }}$ \\
\hline & & & 1508 & 1432 & 1488 & 1413 & $A_{\mathrm{g}}$ & $\delta \mathrm{CH}_{2 \text { (ring) }}$ \\
\hline & & 1434 & 1508 & 1432 & 1488 & 1413 & $A_{\mathrm{u}}^{\mathrm{s}}$ & $\delta \mathrm{CH}_{2 \text { (chain) }}$ \\
\hline & 1430 & & 1504 & 1429 & 1497 & 1422 & $A_{\mathrm{g}}$ & $\delta \mathrm{CH}_{2 \text { (chain) }}$ \\
\hline & & & 1486 & 1412 & 1517 & 1441 & $A_{\mathrm{g}}^{b}$ & $\beta \mathrm{NH}$ \\
\hline & & & 1485 & 1411 & 1516 & 1440 & $A_{\mathrm{u}}^{\mathrm{s}}$ & $\beta \mathrm{NH}$ \\
\hline 1385 & 1386 & & 1460 & 1387 & 1444 & 1372 & $A_{\mathrm{g}}$ & $\omega \mathrm{CH}_{2 \text { (chain) }}$ \\
\hline & & 1377 & 1455 & 1382 & 1434 & 1362 & $A_{\mathrm{u}}^{\mathrm{s}}$ & $\omega \mathrm{CH}_{2 \text { (chain) }}$ \\
\hline & 1372 & & 1436 & 1364 & 1452 & 1379 & $A_{\mathrm{g}}$ & $\omega \mathrm{CH}_{2 \text { (ring) }}$ \\
\hline 1365 & & & 1432 & 1360 & 1451 & 1378 & $A_{\mathrm{u}}$ & $\omega \mathrm{CH}_{2 \text { (ring) }}$ \\
\hline & 1367 & & 1431 & 1359 & 1428 & 1356 & $A_{\mathrm{g}}$ & $\omega \mathrm{CH}_{2 \text { (ring) }}$ \\
\hline 1351 & & 1355 & 1424 & 1353 & 1415 & 1344 & $A_{\mathrm{u}}^{\mathrm{z}}$ & $\omega \mathrm{CH}_{2 \text { (ring) }}$ \\
\hline & 1351 & & 1406 & 1336 & 1400 & 1330 & $A_{\mathrm{g}}$ & $\omega \mathrm{CH}_{2 \text { (ring) }}$ \\
\hline 1338 & & & 1398 & 1328 & 1399 & 1329 & $A_{\mathrm{u}}^{\mathrm{s}}$ & $\omega \mathrm{CH}_{2 \text { (ring) }}$ \\
\hline 1314 & & 1317 & 1377 & 1308 & 1350 & 1280 & $A_{\mathrm{u}}$ & $\tau \mathrm{CH}_{2 \text { (chain) }}$ \\
\hline & 1317 & & 1372 & 1303 & 1361 & 1285 & $A_{\mathrm{g}}$ & $\tau \mathrm{CH}_{2 \text { (ring) }}$ \\
\hline 1299 & 1304 & & 1371 & 1302 & 1375 & 1293 & $A_{\mathrm{g}}^{\circ}$ & $\omega \mathrm{CH}_{2 \text { (chain) }}$ \\
\hline & & 1293 & 1368 & 1299 & 1353 & 1282 & $A_{\mathrm{u}}$ & $\tau \mathrm{CH}_{2 \text { (ring) }}$ \\
\hline & & & 1361 & 1293 & 1347 & 1264 & $A_{\mathrm{g}}$ & $\tau \mathrm{CH}_{2 \text { (chain) }}$ \\
\hline 1278 & 1273 & & 1348 & 1280 & 1297 & 1216 & $A_{\mathrm{g}}^{\mathrm{z}}$ & $\tau \mathrm{CH}_{2 \text { (chain) }}$ \\
\hline 1256 & & 1264 & 1334 & 1267 & 1331 & 1255 & $A_{\mathrm{u}}$ & $\tau \mathrm{CH}_{2 \text { (ring) }}$ \\
\hline 1240 & & 1238 & 1304 & 1239 & 1280 & 1187 & $A_{\mathrm{u}}$ & $\omega \mathrm{CH}_{2 \text { (chain) }}$ \\
\hline 1218 & 1224 & & 1295 & 1230 & 1321 & 1253 & $A_{\mathrm{g}}$ & $\tau \mathrm{CH}_{2 \text { (ring) }}$ \\
\hline & 1213 & & 1287 & 1223 & 1319 & 1248 & $A_{\mathrm{g}}$ & $\tau \mathrm{CH}_{2 \text { (ring) }}$ \\
\hline & & 1213 & 1281 & 1217 & 1314 & 1232 & $A_{\mathrm{u}}$ & $\tau \mathrm{CH}_{2 \text { (ring) }}$ \\
\hline 1163 & & 1179 & 1261 & 1198 & 1250 & 1167 & $A_{\mathrm{u}}$ & $\tau \mathrm{NH}_{2}+\tau \mathrm{CH}_{2(\text { chain })}$ \\
\hline & 1185 & & 1244 & 1182 & 1229 & 1143 & $A_{\mathrm{g}}$ & $\tau \mathrm{NH}_{2}+\rho \mathrm{CH}_{2(\text { chain })}$ \\
\hline & & 1146 & 1184 & 1125 & 1170 & 1104 & $A_{\mathrm{u}}^{\mathrm{z}}$ & $\tau \mathrm{CH}_{2 \text { (chain) }}+\tau \mathrm{CH}_{2 \text { (ring) }}$ \\
\hline & 1147 & & 1167 & 1109 & 1112 & 1051 & $A_{\mathrm{g}}$ & $\nu \mathrm{C}-\mathrm{C}$ \\
\hline 1136 & 1131 & & 1166 & 1108 & 1200 & 1120 & $A_{\mathrm{g}}^{\mathrm{z}}$ & $\rho \mathrm{CH}_{2 \text { (chain) }}$ \\
\hline & & 1133 & 1163 & 1105 & 1203 & 1140 & $A_{\mathrm{u}}$ & $\omega \mathrm{NH}_{2}$ \\
\hline & 1120 & & 1142 & 1085 & 1112 & 1051 & $A_{\mathrm{g}}$ & $\nu \mathrm{C}-\mathrm{C}$ \\
\hline & & & 1130 & 1073 & 1162 & 1099 & $A_{\mathrm{u}}^{\circ}$ & $\nu \mathrm{C}-\mathrm{N}$ \\
\hline & 1108 & & 1127 & 1071 & 1179 & 1111 & $A_{\mathrm{g}}$ & $\omega \mathrm{NH}_{2}$ \\
\hline
\end{tabular}


Table 3 (continued)

\begin{tabular}{|c|c|c|c|c|c|c|c|c|}
\hline \multicolumn{3}{|l|}{ Experimental } & \multirow[b]{2}{*}{ Calc. } & \multirow[b]{2}{*}{ Calc. $(\text { scaled })^{a}$} & \multirow[b]{2}{*}{ Calc. SCRF } & \multirow[b]{2}{*}{ Calc. SCRF (scaled) ${ }^{a}$} & \multirow[b]{2}{*}{ Sym. } & \multirow[b]{2}{*}{ Tentative assignment ${ }^{c}$} \\
\hline INS & Raman & FTIR & & & & & & \\
\hline \multirow[t]{2}{*}{1085} & & 1085 & 1122 & 1066 & 1157 & 1056 & $A_{\mathrm{u}}$ & $\nu \mathrm{C}-\mathrm{N}$ \\
\hline & & & 1107 & 1052 & 1101 & 1040 & $A_{\mathrm{u}}$ & $\nu \mathrm{C}-\mathrm{N}$ \\
\hline 1070 & 1064 & & 1100 & 1045 & 1095 & 1031 & $A_{\mathrm{g}}$ & $\nu \mathrm{C}-\mathrm{C}_{\text {(chain) }}$ \\
\hline \multirow[t]{8}{*}{1057} & 1055 & & 1098 & 1043 & 1085 & 1031 & $A_{\mathrm{g}}^{b}$ & $\nu \mathrm{C}-\mathrm{N}$ \\
\hline & & 1057 & 1092 & 1037 & 1016 & 951 & $A_{\mathrm{u}}$ & $\nu \mathrm{C}-\mathrm{N}$ \\
\hline & & & 1082 & 1028 & 1106 & 1046 & $A_{\mathrm{g}}$ & $\gamma \mathrm{NH}$ \\
\hline & & & 1065 & 1012 & 1085 & 1020 & $A_{\mathrm{u}}^{\mathrm{s}}$ & $\gamma \mathrm{NH}$ \\
\hline & & & 1058 & 1005 & 1074 & 1018 & $A_{\mathrm{g}}$ & $\nu \mathrm{C}-\mathrm{C}$ \\
\hline & & & 1052 & 999 & 1001 & 920 & $A_{\mathrm{g}}^{\mathrm{g}}$ & $\nu \mathrm{C}-\mathrm{N}$ \\
\hline & & 969 & 1025 & 974 & 1072 & 965 & $A_{\mathrm{u}}^{\mathrm{s}}$ & $\nu \mathrm{C}-\mathrm{C}$ \\
\hline & & 918 & 977 & 928 & 968 & 912 & $A_{\mathrm{u}}$ & $\nu \mathrm{C}-\mathrm{C}$ \\
\hline \multirow[t]{2}{*}{930} & 932 & & 970 & 921 & 960 & 901 & $A_{\mathrm{g}}$ & $\rho \mathrm{CH}_{2 \text { (ring) }}$ \\
\hline & & 899 & 945 & 898 & 949 & 887 & $A_{\mathrm{u}}^{\mathrm{s}}$ & $\rho \mathrm{CH}_{2 \text { (chain) }}$ \\
\hline \multirow[t]{4}{*}{906} & & & 939 & 892 & 934 & 885 & $A_{\mathrm{u}}$ & $\rho \mathrm{CH}_{2 \text { (ring) }}$ \\
\hline & 903 & & 937 & 890 & 932 & 857 & $A_{\mathrm{g}}$ & $\rho \mathrm{CH}_{2 \text { (ring) }}$ \\
\hline & 861 & & 884 & 840 & 902 & 854 & $A_{\mathrm{g}}^{\circ}$ & $\rho \mathrm{CH}_{2 \text { (ring) }}$ \\
\hline & & 862 & 883 & 839 & 899 & 796 & $A_{\mathrm{u}}^{\mathrm{s}}$ & $\rho \mathrm{CH}_{2 \text { (ring) }}$ \\
\hline 812 & 814 & & 826 & 785 & 838 & 793 & $A_{\mathrm{g}}$ & $\rho \mathrm{CH}_{2 \text { (ring) }}$ \\
\hline \multirow[t]{3}{*}{789} & & 790 & 823 & 782 & 835 & 773 & $A_{\mathrm{u}}$ & $\rho \mathrm{CH}_{2 \text { (ring) }}$ \\
\hline & & & 811 & 770 & 814 & 714 & $A_{\mathrm{g}}$ & $\rho \mathrm{CH}_{2 \text { (chain) }}$ \\
\hline & & & 750 & 712 & 752 & 712 & $A_{\mathrm{u}}^{\mathrm{s}}$ & $\rho \mathrm{CH}_{2 \text { (chain) }}$ \\
\hline $707 / 725 / 745$ & & 706/739 & 680 & 680 & 750 & 711 & $A_{\mathrm{u}}$ & $\rho \mathrm{NH}_{2}$ \\
\hline & $703 / 740$ & & 680 & 680 & 748 & 560 & $A_{\mathrm{g}}$ & $\rho \mathrm{NH}_{2}$ \\
\hline 612 & 598 & & 572 & 572 & 590 & 558 & $A_{\mathrm{g}}^{\mathrm{s}}$ & $\beta$ ring \\
\hline 576 & & 579 & 560 & 560 & 587 & 500 & $A_{\mathrm{u}}^{\circ}$ & $\beta$ ring \\
\hline 544 & & 552 & 549 & 549 & 502 & 477 & $A_{\mathrm{u}}$ & $\delta \mathrm{N}-\mathrm{C}-\mathrm{C}_{(\text {ring })}$ \\
\hline & 514 & & 531 & 531 & 526 & 499 & $A_{\mathrm{g}}$ & $\delta \mathrm{C}-\mathrm{N}-\mathrm{C}$ \\
\hline & & & 474 & 474 & 499 & 493 & $A_{\mathrm{u}}$ & $\delta \mathrm{C}-\mathrm{N}-\mathrm{C}$ \\
\hline 504 & 501 & 502 & 437 & $485^{b}$ & 480 & $533^{b}$ & $A_{\mathrm{u}}$ & $\nu_{\mathrm{s}} \mathrm{Pd}-\mathrm{N}$ \\
\hline & & & 436 & $484^{b}$ & 456 & $506^{b}$ & $A_{\mathrm{g}}$ & $\nu_{\mathrm{s}} \mathrm{Pd}-\mathrm{N}$ \\
\hline 457 & 464 & & 471 & 471 & 428 & 428 & $A_{\mathrm{g}}^{\circ}$ & $\tau \mathrm{CC}_{\text {ring }}$ \\
\hline 450 & 449 & & 398 & $442^{b}$ & 499 & $554^{b}$ & $A_{\mathrm{g}}$ & $\nu_{\text {as }} \mathrm{Pd}-\mathrm{N}$ \\
\hline 442 & & 449 & 393 & $436^{b}$ & 493 & $547^{b}$ & $A_{\mathrm{u}}$ & $\nu_{\text {as }} \mathrm{Pd}-\mathrm{N}$ \\
\hline & 324 & - & 345 & $321^{b}$ & 320 & $298^{b}$ & $A_{\mathrm{g}}$ & $\nu_{\mathrm{s}} \mathrm{Pd}-\mathrm{Cl}$ \\
\hline & & - & 343 & $319^{b}$ & 319 & $297^{b}$ & $A_{\mathrm{u}}$ & $\nu_{\mathrm{s}} \mathrm{Pd}-\mathrm{Cl}$ \\
\hline $361 / 375$ & & - & 337 & 337 & 280 & 280 & $A_{\mathrm{u}}$ & $\gamma$ ring \\
\hline & 309 & - & 326 & $303^{b}$ & 300 & $279^{b}$ & $A_{\mathrm{g}}$ & $\nu_{\mathrm{as}} \mathrm{Pd}-\mathrm{Cl}$ \\
\hline 295 & & - & 315 & $293^{b}$ & 293 & $272^{b}$ & $A_{\mathrm{u}}^{\mathrm{s}}$ & $\nu_{\mathrm{as}} \mathrm{Pd}-\mathrm{Cl}$ \\
\hline 286 & 276 & - & 282 & $262^{b}$ & 242 & $225^{b}$ & $A_{\mathrm{g}}$ & $\delta \mathrm{N}-\mathrm{Pd}-\mathrm{N}$ \\
\hline & & - & 281 & $261^{b}$ & 230 & $214^{b}$ & $A_{\mathrm{u}}$ & $\delta \mathrm{N}-\mathrm{Pd}-\mathrm{N}$ \\
\hline 242 & 256 & - & 265 & 265 & 192 & 192 & $A_{\mathrm{g}}$ & $\gamma$ ring \\
\hline 236 & 237 & - & 249 & 249 & 310 & 310 & $A_{\mathrm{g}}$ & $\beta \mathrm{C}-\mathrm{C}-\mathrm{C}$ "swinging" \\
\hline 216 & & - & 222 & 222 & 349 & 349 & $A_{\mathrm{u}}^{\mathrm{s}}$ & "ring breathing" \\
\hline & & - & 198 & 198 & 214 & 214 & $A_{\mathrm{u}}$ & $\gamma_{1} \mathrm{C}-\mathrm{C}-\mathrm{C}_{\mathrm{chain}}$ \\
\hline 196 & 203 & - & 185 & $205^{b}$ & 140 & $155^{b}$ & $A_{\mathrm{o}}$ & $\delta \mathrm{N}-\mathrm{Pd}-\mathrm{Cl}$ \\
\hline & & - & 179 & $199^{b}$ & 136 & $151^{b}$ & $A_{\mathrm{u}}$ & $\delta \mathrm{N}-\mathrm{Pd}-\mathrm{Cl}$ \\
\hline 168 & 164 & - & 167 & 167 & 223 & 223 & $A_{\mathrm{g}}$ & $\tau \mathrm{C}-\mathrm{N}_{\text {ring }}$ \\
\hline 153 & 152 & - & 150 & 150 & 158 & 158 & $A_{\mathrm{g}}^{b}$ & $\gamma_{2} \mathrm{C}-\mathrm{C}-\mathrm{C}_{\text {chain }}$ \\
\hline 160 & & - & 148 & 148 & 117 & 117 & $A_{\mathrm{u}}^{\mathrm{s}}$ & $\gamma_{3} \mathrm{C}-\mathrm{C}-\mathrm{C}_{\text {chain }}$ \\
\hline & & - & 142 & 142 & 143 & 143 & $A_{\mathrm{u}}$ & $\delta \mathrm{Cl}-\mathrm{Pd}-\mathrm{Cl}$ \\
\hline & & - & 140 & 140 & 142 & 142 & $A_{\mathrm{g}}$ & $\delta \mathrm{Cl}-\mathrm{Pd}-\mathrm{Cl}$ \\
\hline & & - & 127 & 127 & 110 & 110 & $A_{\mathrm{g}}$ & $\gamma_{4} \mathrm{C}-\mathrm{C}-\mathrm{C}_{\text {chain }}$ \\
\hline 117 & & - & 121 & 121 & 167 & 167 & $A_{\mathrm{u}}^{\mathrm{s}}$ & $\tau \mathrm{C}-\mathrm{N}_{\text {ring }}$ \\
\hline 103 & & - & 104 & 104 & 155 & 155 & $A_{\mathrm{g}}$ & $\gamma_{5} \mathrm{C}-\mathrm{C}-\mathrm{C}_{\text {chain }}$ \\
\hline & & - & 89 & 89 & 80 & 80 & $A_{\mathrm{u}}$ & $\gamma \mathrm{N}-\mathrm{Pd}-\mathrm{Cl}$ \\
\hline & & - & 88 & 88 & 42 & 42 & $A_{\mathrm{g}}$ & $\gamma \mathrm{N}-\mathrm{Pd}-\mathrm{Cl}$ \\
\hline & & - & 75 & 75 & 73 & 73 & $\stackrel{\circ}{A_{\mathrm{u}}}$ & $\gamma^{\prime} \mathrm{N}-\mathrm{Pd}-\mathrm{Cl}$ \\
\hline & & - & 74 & 74 & 71 & 71 & $A_{\mathrm{g}}$ & $\gamma^{\prime} \mathrm{N}-\mathrm{Pd}-\mathrm{Cl}$ \\
\hline & & - & 70 & 70 & 111 & 111 & $A_{\mathrm{u}}$ & Skeletal modes \\
\hline & & - & 52 & 52 & 98 & 98 & $A_{\mathrm{g}}$ & Skeletal modes \\
\hline 30 & & - & 32 & 32 & 31 & 31 & $A_{\mathrm{u}}^{\circ}$ & Skeletal modes \\
\hline 25 & & - & 26 & 26 & 26 & 26 & $A_{\mathrm{g}}$ & Skeletal modes \\
\hline & & - & 23 & 23 & 23 & 23 & $A_{\mathrm{u}}$ & Skeletal modes \\
\hline & & - & 11 & 11 & 6 & 6 & $A_{\mathrm{u}}$ & Skeletal modes \\
\hline
\end{tabular}

${ }^{a}$ Wavenumbers above $700 \mathrm{~cm}^{-1}$ were scaled by 0.9499 , accordingly to Merrick et al. ${ }^{39}{ }^{b}$ Wavenumbers scaled by 3 different scaling factors $\lambda_{1}=0.93$, $\lambda_{2}=1.01$ and $\lambda_{3}=1.11$ where $\lambda_{1}-\nu \mathrm{NH}_{3}, \delta_{\mathrm{as}} \mathrm{NH}_{3}, \nu \mathrm{Pd}-\mathrm{Cl}, \delta \mathrm{N}-\mathrm{Pd}-\mathrm{N} ; \lambda_{2}-\delta_{\mathrm{s}} \mathrm{NH}_{3}, \rho \mathrm{NH}_{3}, \gamma \mathrm{N}-\mathrm{Pd}-\mathrm{Cl} ; \lambda_{3}-\nu \mathrm{Pd}-\mathrm{N}, \delta \mathrm{N}-\mathrm{Pd}-\mathrm{Cl}$, according to Fiuza et al. ${ }^{17}$ ${ }^{c} \nu=$ stretching; $\delta, \beta=$ in-plane deformation; $\rho$ = rocking; $\tau$ = torsion; $\gamma$ and $\gamma^{\prime}=$ in phase and out of phase out-of-plane deformation. 

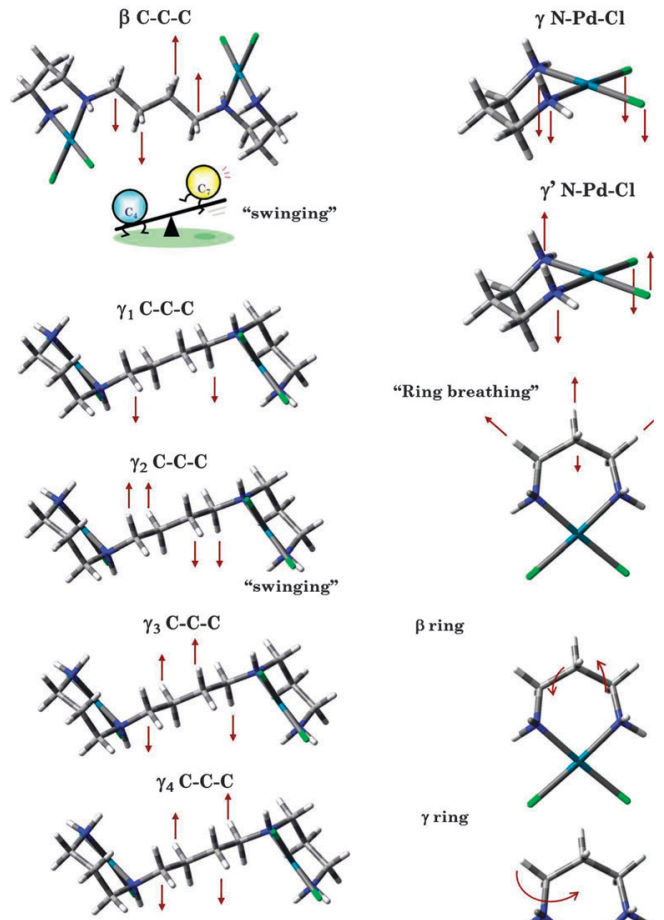

$\gamma$ ring
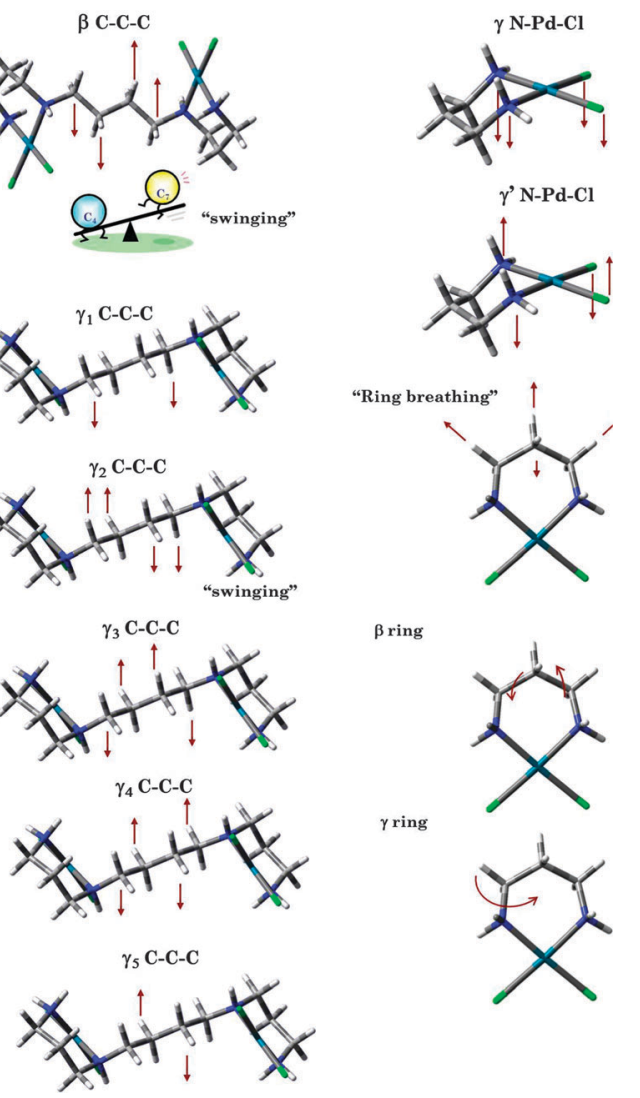

Fig. 4 Schematic of selected vibrational modes for $\mathrm{Pd}_{2}-\mathrm{Spm}$ (and nomenclature used in this work).

Table 4 Calculated (mPW1PW/LANL2DZ/6-31G*) scaling factors for selected vibrational modes, regarding different $\mathrm{Pd}(॥)$-amine complexes

\begin{tabular}{llll}
\hline \multirow{2}{*}{ Compound } & \multicolumn{3}{l}{ Scaling factor for each vibrational mode } \\
\cline { 2 - 4 } & $\nu \mathrm{NH}_{3} / \nu \mathrm{NH}_{2}$ & $\nu \mathrm{Pd}-\mathrm{N}$ & $\nu \mathrm{Pd}-\mathrm{Cl}$ \\
\hline $\mathrm{cDDPd}$ & 0.91 & 1.13 & 0.93 \\
{$\left[\mathrm{Pd}\left(\mathrm{NH}_{3}\right)_{4}\right] \cdot 2 \mathrm{Cl} \cdot \mathrm{H}_{2} \mathrm{O}$} & 0.93 & 1.10 & - \\
$\left.\left[\mathrm{Pd}^{\mathrm{N}} \mathrm{NH}_{3}\right)_{3}(\mathrm{DMSO})\right] \cdot 2 \mathrm{Cl}$ & 0.92 & 1.11 & - \\
{$\left[\mathrm{PdCl}_{2}(\mathrm{en})\right]$} & 0.91 & 1.07 & 0.90 \\
{$\left[\mathrm{PdCl}_{2}(\mathrm{dap})\right]$} & 0.92 & 1.20 & 0.89 \\
{$\left[\mathrm{Pd}_{2}-\mathrm{Spm}\right]$} & 0.92 & 1.17 & 0.94 \\
Average & 0.92 & 1.13 & 0.92 \\
\end{tabular}

was undertaken by a combined spectroscopic and quantum mechanical calculation methodology. FTIR, Raman and INS spectra were recorded and the theoretical analysis was carried out at the DFT level, for both the isolated molecule and a twomolecule model.

It was shown that the intermolecular interactions within the crystal lattice are of the utmost importance for this type of polynuclear polyamine chelate. A simple isolated molecule calculation was found not to suffice for predicting the molecular properties of such a system, in contrast to that reported (by the authors) for mononuclear counterparts. Although the calculations performed for the two-molecule species yielded slightly better results, the structural improvements were not noteworthy. Furthermore, when no X-ray data are available and several possible two-molecule geometries are to be tested, this approach becomes excessively demanding (in terms of computational costs).

In order to further improve the representation of this type of $\operatorname{Pd}(\mathrm{II})$-amine complex, it is of paramount importance to develop new basis sets as recently undertaken for Pt(II) complexes ${ }^{19,42}$ (which was beyond the scope of this work). At the moment, it seems that the precise estimate of one type of metal-ligand bond length leads to uncertainty in the other one, and an improvement of the bond lengths results in a worse description of the bond angles. Therefore, when considering only the prediction of the structural parameters, some doubts can arise as to the most suitable theoretical approach. For the representation of the vibrational profiles, in turn, the LANL2DZ/6-31G* theory level was shown to attain a high degree of agreement with the experiment, while the enhancement obtained with higher theory levels was not worth the associated computational cost. Optimization of the theoretical methodology for this type of $\mathrm{Pd}(\mathrm{II})$ polynuclear polyamine agent will hopefully allow the establishment of accurate and reliable SARs and enable the prediction of other important properties relevant to their anticancer activity. Finally, while plane-wave calculations are of utmost importance for estimating the properties of a molecule in the solid state, an up-to-date allelectron basis set for palladium(II) is also crucial, since studies for an isolated molecule cannot be ruled out for large polynuclear complexes bearing biological properties.

The data obtained in this work shows an inverse relationship between the strength of the $\mathrm{Pd}-\mathrm{Cl}$ bond and the antiproliferative effect of $\mathrm{Pd}_{2}-\mathrm{Spm}$ against cancer cells, i.e., the weaker the $\mathrm{Pd}-\mathrm{Cl}$ bonds the higher the complex's activity. The antiproliferative activity of such a compound is determined by several other factors. However, this evidence may indicate that these Pd(II)amine chelates (comprising cisplatin-like moieties) could display a similar mode of action to that of cisplatin, involving chloride hydrolysis inside the cell as their major activation step.

\section{Acknowledgements}

The authors acknowledge financial support from the Portuguese Foundation for Science and Technology - UID/MULTI/00070/2013. SF thanks FCT - the Portuguese Foundation for Science and Technology - SFRH/BPD/75334/2010 scholarship. The INS work was supported by the European Commission under the 7th Framework Programme through the Key Action: Strengthening the European Research Area, Research Infrastructures (Contract no.: CP-CSA_INFRA-2008-1.1.1 Number 226507-NMI3). Laboratório Associado CICECO (University of Aveiro, Portugal) is also acknowledged for access to the FT-Raman and FTIR spectrometers.

\section{References}

1 S. Ray, R. Mohan, J. K. Singh, M. K. Samantaray, M. M. Shaikh, D. Panda and P. Ghosh, J. Am. Chem. Soc., 2007, 129, 15042-15053.

2 E. Gao, C. Liu, M. Zhu, H. Lin, Q. Wu and L. Liu, Anti-Cancer Agents Med. Chem., 2009, 9, 356-368. 
3 F. Aria, B. Cevatemrea, E. I. I. Armutakb, N. Aztopala, V. T. Yilmazc and E. Ulukaya, Bioorg. Med. Chem., 2014, 22, 4948-4954.

4 A. Garoufis, S. K. Hadjikakou and N. Hadjiliadis, Coord. Chem. Rev., 2009, 253, 1384-1397.

5 E. Sindhuja, R. Ramesh, N. Dharmaraj and Y. Liu, Inorg. Chim. Acta, 2014, 416, 1-12.

6 J. L. Butour, S. Wimmer, F. Wimmer and P. Castan, Chem.-Biol. Interact., 1997, 104, 165-178.

7 F. Shaheen, A. Badshah, M. Gielen, C. Gieck, M. Jamil and D. Vos, J. Organomet. Chem., 2008, 693, 1117-1126.

8 F. Shaheen, A. Badshah, M. Gielen, G. Croce, U. Florke, D. de Vos and S. Ali, J. Organomet. Chem., 2010, 695, 315-322.

9 H. A. El-Asmy, I. S. Butler, Z. S. Mouhri, B. J. Jean-Claude, M. S. Emmam and S. I. Mostafa, J. Mol. Struct., 2014, 1059, 193-201.

10 P. Vranec and I. Potocnak, J. Mol. Struct., 2013, 1041, 219-226.

11 R. A. Haque, A. W. Salman, S. Budagumpi, A. A. A. Abdullah and A. M. S. A. Majid, Metallomics, 2013, 5, 760-769.

12 M. P. M. Marques, ISRN Spectrosc., 2013, 2013, 1-29.

13 D. Kovala-Demertzi, A. Alexandratos, A. Papageorgiou, P. N. Yadav, P. Dalezis and M. A. Demertzis, Polyhedron, 2008, 27, 2731-2738.

14 G. Codina, A. Caubet, C. López, V. Moreno and E. Molins, Helv. Chim. Acta, 1999, 82, 1025.

15 A. S. Soares, S. M. Fiuza, M. J. Gonçalves, L. A. E. Batista de Carvalho, M. P. M. Marques and A. M. Urbano, Lett. Drug Des. Discovery, 2007, 4, 460-463.

16 S. M. Fiuza, J. Holy, L. A. E. Batista de Carvalho and M. P. M. Marques, Chem. Biol. Drug Des., 2011, 77, 477-488.

17 S. M. Fiuza, A. M. Amado, H. F. Dos Santos, M. P. M. Marques and L. A. E. Batista de Carvalho, Phys. Chem. Chem. Phys., 2010, 12, 14309-14321.

18 A. M. Amado, S. M. Fiuza, M. P. M. Marques and L. A. E. Batista de Carvalho, J. Chem. Phys., 2007, 127, 185104.

19 D. Paschoal, B. L. Marcial, J. F. Lopes, W. B. De Almeida and H. F. Dos Santos, J. Comput. Chem., 2012, 33, 2292-2302.

20 http://www.isis.stfc.ac.uk/.

21 M. J. Frisch, G. W. Trucks, H. B. Schlegel, G. E. Scuseria, M. A. Robb, J. R. Cheeseman, J. A. Montgomery Jr., T. Vreven, K. N. Kudin, J. C. Burant, J. M. Millam, S. S. Iyengar, J. Tomasi, V. Barone, B. Mennucci, M. Cossi, G. Scalmani, N. Rega, G. A. Petersson, H. Nakatsuji, M. Hada, M. Ehara, K. Toyota, R. Fukuda, J. Hasegawa, M. Ishida, T. Nakajima, Y. Honda, O. Kitao, H. Nakai, M. Klene, X. Li, J. E. Knox, H. P. Hratchian, J. B. Cross, V. Bakken, C. Adamo, J. Jaramillo, R. Gomperts, R. E. Stratmann, O. Yazyev, A. J. Austin, R. Cammi, C. Pomelli, J. W. Ochterski, P. Y. Ayala, K. Morokuma,
G. A. Voth, P. Salvador, J. J. Dannenberg, V. G. Zakrzewski, S. Dapprich, A. D. Daniels, M. C. Strain, O. Farkas, D. K. Malick, A. D. Rabuck, K. Raghavachari, J. B. Foresman, J. V. Ortiz, Q. Cui, A. G. Baboul, S. Clifford, J. Cioslowski, B. B. Stefanov, G. Liu, A. Liashenko, P. Piskorz, I. Komaromi, R. L. Martin, D. J. Fox, T. Keith, M. A. Al-Laham, C. Y. Peng, A. Nanayakkara M. Challacombe, P. M. W. Gill, B. Johnson, W. Chen, M. W. Wong, C. Gonzalez and J. A. Pople, Gaussian 03, Revision D.01, Gaussian, Inc., Wallingford, CT, 2004.

22 P. J. Hay and W. R. Wadt, J. Chem. Phys., 1985, 82, 299-310. 23 M. E. Friedlander, J. M. Howell and G. Snyder, J. Chem. Phys., 1982, 77, 1921-1929.

24 A. W. Ehlers, M. Bohme, S. Dapprich, A. Gobbi, A. Hollwarth, V. Jonas, K. F. Kohler, R. Stegmann, A. Veldkamp and G. Frenking, Chem. Phys. Lett., 1993, 208, 111-114.

25 C. Adamo and V. Barone, J. Chem. Phys., 1998, 108, 664-675. 26 J. P. Perdew, K. Burke and Y. Wang, Phys. Rev. B: Condens. Matter Mater. Phys., 1996, 54, 16533.

27 S. Padrão, S. M. Fiuza, A. M. Amado, A. M. A. da Costa and L. A. E. Batista de Carvalho, J. Phys. Org. Chem., 2011, 24, 110-121.

28 S. Grimme, J. Comput. Chem., 2006, 27, 1787-1799.

29 S. F. Boys and F. Bernardi, Mol. Phys., 1970, 19, 558-566.

30 M. D. Hanwell, D. E Curtis, D. C. Lonie, T. Vandermeersch,

E. Zurek and G. R. Hutchison, J. Cheminf., 2012, 4, 17.

31 R. L. Lopes, M. P. M. Marques, R. Valero, J. Tomkinson and L. A. E. Batista de Carvalho, Spectrosc. Int. J., 2012, 27, 273-292.

32 M. P. M. Marques, R. Valero, S. F. Parker, J. Tomkinson and L. A. E. Batista de Carvalho, J. Phys. Chem. B, 2013, 117, 6421-6429.

33 R. L. Lopes, R. Valero, J. Tomkinson, M. P. M. Marques and L. A. E. Batista de Carvalho, New J. Chem., 2013, 37, 2691-2699.

34 M. P. M. Marques, L. A. E. Batista de Carvalho, R. Valero, N. F. L. Machado and S. F. Parker, Phys. Chem. Chem. Phys., 2014, 16, 7491-7500.

35 S. D. Kirik, L. A. Solovyov and M. L. Blokhina, Acta Crystallogr., Sect. B: Struct. Sci., 1996, 52, 909-916.

36 P. Banerjee, Coord. Chem. Rev., 1999, 190-192, 19-28.

37 A. Eastman, Biochemistry, 1983, 22, 3927-3933.

38 M. Kartalou and J. M. Essigmann, Mutat. Res., 2001, 478, 1-21. 39 J. P. Merrick, D. Moran and L. Radom, J. Phys. Chem. A, 2007, 111, 11683-11700.

40 M. P. M. Marques, L. A. E. Batista de Carvalho and J. Tomkinson, J. Phys. Chem. A, 2002, 106, 2473-2482.

41 L. A. E. Batista de Carvalho, M. P. M. Marques and J. Tomkinson, J. Phys. Chem. A, 2006, 110, 12947-12954.

42 R. C. De Berrêdo and F. E. Jorge, THEOCHEM, 2010, 961, 107-112. 